\title{
RENEWABLE ENERGY SOURCES AS A DETERMINANT OF THE MODERN ECONOMY - POLISH HOUSEHOLD SECTOR PERSPECTIVE
}

\author{
Małgorzata Leszczyńska, $\mathrm{PhD}^{1}$; Małgorzata Lechwar, Eng PhD²; \\ Katarzyna Puchalska, Eng PhD ${ }^{3}$
}

Faculty of Economics, University of Rzeszów

\begin{abstract}
The main purpose of the article is to present changes in the acquisition and use of energy from renewable sources by households in Poland. The role of this sector in total energy consumption was indicated. Changes in energy expenditure in households were also assessed. Secondary data from public statistics were used. The household sector in Poland is characterized by the highest energy consumption in the structure of final energy consumption in the national economy, and energy expenditure is an important expenditure item in the household budget.. The amount of costs related to RES investment is a significant barrier to household expenditure. However, this investment should be seen as a means of reducing the share of energy costs in the home budget in a long-term perspective.
\end{abstract}

Keywords: renewable energy sources, economy, households JEL codes: Q42, Q47, P18, O13

\section{INTRODUCTION}

Although the energy intensity of the Polish economy is declining, the demand for energy is still much higher than in countries of the 'old EU'. Assuming an average annual 3\% GDP growth by 2030 , the demand of the Polish economy for energy may amount to 65.5 Mtoe.

This, in turn, will lead to significant changes in the structure of the energy mix, which results from Poland's commitments to EU climate policy. Among priority projects of energy policy in Poland, an im- portant place is foreseen for the diversification of the energy generation structure through the development of renewable and dispersed energy.

Renewable energy sources should constitute an important element of the electric power system, and increasing their share in final energy consumption will depend, to a great extent, on the progress in achieving economic maturity by individual technologies and the use of national potential (Ministerstwo Gospodarki, 2014).

Renewable energy sources also emphasize the importance of creating conditions for the stable and

${ }^{1}$ Corresponding author: Cwiklińskiej 2, 35-601 Rzeszów, Poland, leszczynska.malgorzata@wp.pl, +48 606685026

${ }^{2}$ Corresponding author: Cwiklińskiej 2, 35-601 Rzeszów, Poland, lechwarm@ur.edu.pl, +48 606671673

${ }^{3}$ Corresponding author: Cwiklińskiej 2, 35-601 Rzeszów, Poland, k_puch@univ.rzeszow.pl, +48 604885600 
sustainable development of the national economy, meeting the energy needs of enterprises and households, ensuring energy security while, at the same time, respecting the natural environment. It should contribute, among others, to: a reduction in the country's demand for fuel and non-renewable energy, an increase in energy security of the country, an increase in competitiveness and innovativeness of the economy, the development of a market for energy-efficient equipment and services, the creation of new jobs in the green service sector and a reduction in household expenditure for energy purposes, as well as restrictions in the area of energy poverty (European Commission, 2015).

The aim of the article is to emphasize the importance of renewable energy for the economy in rural areas and in the household sector in Poland. In addition, an attempt was made to indicate the importance of using renewable energy sources for the benefit of the modern economy and its rural areas. This is important in the context of the creation of household behaviour by technological factors that set new trends in the socio-economic development of modern economies.

\section{THEORETICAL BACKGROUND}

Modernity of the economy is associated with the socalled fourth industrial revolution defined in Poland as Economy 4.0, which relies on the integration of digital and physical systems (PKN Orlen, 2017). It affects all spheres of life, and the technologies leading in it, apart from the entire area of creation and development of virtual reality, it includes innovation in the energy sector, comprising energy and RES storage. Households can use this energy for space and water heating, as well as the use of electrical equipment and lighting, and those related to agriculture, also for production purposes. European economies need new energy sources. Therefore, it is necessary to transform them into a low-carbon and sustainable economy that uses resources more effectively (Trębska, 2018). In many EU documents, it is emphasized, alongside the need to increase energy efficiency, the synergistic development of RES (Skoczkowski and Bielecki, 2016).
The implementation of EU provisions on renewable energy in a modern European economy is to contribute not only to counteracting climate change and reducing dependence on energy imports or enhancing energy security, but also to develop the market, new services and innovative energy technologies, to modernize economies.

The basis for the energy union in Europe is the strategy for research and innovation (European Commission, 2010; Malko, Wilczyński and Wojciechowski, 2015). It is to create a new European approach in the energy field to accelerate the transformation of energy systems.

Another important priority is the development of smart grid and smart home technologies. Poland has large and diversified resources of renewable energy sources, though they are still used to a small extent. This potential results from favourable geographic and climatic conditions as well as the large area of the country, offering the opportunity to obtain scattered energy resources, while existing forms of land development are mostly favourable to agricultural use of RES.

The analyses, carried out at a national level, show that the volume of renewable energy resources is not a barrier for the transition to an energy supply from renewable energy determined until 2020 (Wiśniewski, ed., 2011). The Polish village has enormous potential for the development of renewable energy, the use of which would be an important developmental impulse (FREE, 2013).

The efficiency of energy and agricultural policy in rural areas in the development of renewable energy, however, requires regulatory restrictions, political, technological and investment risks for investors, including rural residents (Księżopolski and Pronińska, 2017).

Sustainable rural development, agriculture and fisheries by 2030 take into account, in addition to structural changes, increasing innovation companies operating in agribusiness, improving the quality of human capital, the development of potential environmental issues to strengthen the development of digital, increasing the availability of transport, and under energy: balancing the energy system, through the diversification of sources of energy production and distribution at a local level and the development of 
renewable energy sources in rural areas (Ministerstwo Rolnictwa i Rozwoju Wsi, 2017).

That is why activities in dispersed energy are very important, giving rise to revolutionary changes in the behaviour of farms and households in relation to energy consumption (Popczyk, 2014), but also behaviour resulting from the fact that they will be the main beneficiary of energy balancing areas, i.e. energy clusters (Tokarčík et al., 2017).

\section{MATERIALS AND METHODS}

Realizing the adopted goal was based on subject literature and existing data using the method of desk research. The necessary data and information were gathered on the basis of the documentary method, which is related to the consolidation, processing and analysis of data dispersed among various sources. This documentation research covered actual information collected, i.a. for the purposes of economic policy. Part of the information was recorded in relevant existing documents, studies and publications, in the character of secondary sources.

The article uses comparable balance sheet data for the country and the entire economy as well as relevant household sector reports presented by the Central Statistical Office and the Energy Department of the Ministry of the Economy, as well as Eurostat data. Although, in Poland, on an annual basis, information about the production, acquisition and consumption of all energy by businesses is collected regularly, direct research in the area of households is still sporadic. Since 2002, only three studies have been carried out by the Central Statistical Office.

\section{RESULTS AND DISCUSSION}

In the Polish economy, the consumption structure of energy used is determined by possessed natural resources. The main sources of primary energy are hard coal and lignite. In the case of final consumption, coal fuels are the second most important type of used carriers (their share decreased from $21 \%$ in 2005 to $18 \%$ in 2015).

The most important energy carrier in 2015 were petroleum-derived fuels, the share of which amount- ed to $32 \%$ and did not change compared to 2005 . Among other carriers, there was a decrease in gas consumption (from 15 to $14 \%$ ) and heat (from 12 to $9 \%$ ). An increase in the case of electricity was recorded - from 16 to $18 \%$ and other energy carriers (mainly energy from renewable sources) - from 7 to $10 \%$ (GUS, 2017d).

In Poland, the share of energy from renewable sources in final gross energy consumption is $12 \%$ and is lower in comparison with the EU (17\%). However, it should be emphasized that this indicator has significantly increased since 2006 (by 5 p.p.). By 2020, it is expected to increase to $15 \%$ in Poland and up to $20 \%$ in the EU. From the sectors of the Polish economy, the largest share of energy from RES occurs in power engineering, heating and cooling as well as transport.

In these sectors, this share has been growing steadily since 2006, although, only at present, it is higher than the EU average (GUS, 2017a). In Poland, the structure of obtaining primary energy from renewable sources differs significantly from the European Union economy, which determines the parameters of modernity. Solid fuels (solid biofuels) (44.3\%), hydro power (14.4\%), wind energy (12.7\%) and biogas (biogas) are the most important in the EU (7.7\%), while liquid bioflues and solar energy (account for over 6\% each), municipal waste (for 4.6\%) and geothermal energy (for 3\%). In Poland, the largest share in this structure, as in the EU, constitute solid biofuels, and account for as much as $72 \%$ in Poland. Liquid biofuels and wind energy are also used, and these sources account for about $11 \%$ of the total structure, biogas $(2.6 \%)$ and water energy $(1.8 \%)$. The remaining sources of renewable energy: solar energy, heat pumps, municipal waste and geothermal energy in the overall structure are marginal, because their shares constitute less than 1\% (GUS, 2017a; Górecka-Zbrońska and Zbroński, 2017). Households in Poland have a significant share in national energy consumption. The household sector is the main recipient of final energy in Poland, as this share amounts to $31 \%$. Subsequently, these sectors are: transport (27\%), industry - including construction $(23 \%)$, services $(13 \%)$ and agriculture $(6 \%)$. However, in 2005-2015, the share of industry, households and agriculture in final energy consumption decreased. 
Nevertheless, households remained the largest consumer of energy, despite a decline in their share from 35 to $31 \%$ (industry share decreased from 26 to $24 \%$, and agriculture from 8 to $5 \%$ ) (GUS, 2017d). Poland also belongs to those EU countries in which the share of households in the use of domestic energy was relatively high. In Europe has an average of 16\%, while only 5 countries, except Poland, have $20 \%$ or more of domestic consumption. On average, households consumed approximately 21 GJ of energy per 1 inhabitant.

In the structure of energy consumption in households in Poland the most important are solid fuels, mainly hard coal (at the same time it is an exceptional case in the EU) and wood. Wood was used by about $42 \%$ of households and it was the only significant renewable energy carrier massively used by farms. Other types of biomass were also used, but the popularity of their use was much lower than that of wood. Biomass is mainly used by individual households, especially in the countryside - for the production of heat and preparation of hot usable water. Over the period 2005-2015, an upward trend in the level of solid biomass consumption in households in Poland was observed (Mirowski and Orzechowska, 2015). However, only a small part of households install appliances for the production of their own energy. In households, it is possible, in particular, to obtain electricity, either as a direct or indirect conversion of solar radiation energy in solar collectors or photovoltaic cells (Mirowski and Sornek, 2015).

A small number of households, only $2.6 \%$, performs a building / flat energy audit in general, and only $4 \%$ install equipment for the production of their own energy. However, they are mainly, however solar collectors and heat pumps. While solar collectors are used by one in 56 households, heat pumps are only used by one in 1,250 (GUS, 2017e).

The diversification of renewable energy use also differs between urban and rural areas. Research of the Central Statistical Office shows that urban households did not use solid fuels, heating oil or any form of energy from renewable sources. Increasing the share of renewable energy is only possible in an indirect way, by supplying electricity and heat produced partly or completely from renewable sources.
In turn, among rural households related to agricultural activity, the majority, $89.5 \%$, used fuel wood, and $6.7 \%$ also other fuels from biomass. In such farms, agricultural activity has an impact on the consumption of energy carriers, because it serves both home and production needs, and the distribution of consumption is usually impossible. It is predicted that in the perspective of 2050, in Poland, a significant part of households primarily living in rural areas will have their own sources of energy (microinstallations) enabling at least partial coverage of their current demand for electricity and heat (Ministerstwo Energii, 2015).

Similarly, the structure of energy consumption in Polish households per capita, in conversion to individual energy carriers, indicates the marginal importance of renewable energy sources. In the EU they constitute $2.5 \%$ in the overall structure of energy consumption, while in Poland it is only $1.2 \%$.

The share of electricity from renewable sources in final gross electricity consumption in Poland was only $12.4 \%$, but it increased since 2013 by over 4 p.p. This may be evidence of an increase in ecological awareness of households (GUS, 2016; Trębska, 2018). Expectations of households (approx. 13.5 million in Poland) concern the improvement of living conditions, which requires the provision of certain, but also low-cost energy carriers.

The situation is changing rapidly. In 2012, households acquired $456 \mathrm{TJ}$ of solar energy, compared to 1,943 TJ in 2016 (cf: GUS, 2017a). Currently, however, households are not able to order energy from renewable sources. What is more, the energy obtained from such sources is still more expensive than conventional energy.

In 2002-2015, real electricity prices for households increased by $32 \%$ (GUS, 2017e). According to the Energy Regulatory Office, the price of electricity for a household in 2017 was PLN 0.50/kWh and was higher than in previous years. On the other hand, the share of expenditure per 1 person on all energy carriers in total expenditure increased from 10.5 to $11.4 \%$, and average annual expenses on all energy carriers amounted to over PLN 4,100 (GUS, 2017b, e). It is worth noting that expenses on energy carriers, along with the use of housing and food expenses, constitute 
the largest financial burden on household budgets, as together they absorb half of all expenditure. With the forecast increase in prices for electricity in following years, in Poland, however, interest in reducing expenditure on such energy will increase (Ministerstwo Gospodarki, 2014). Therefore, from a future perspective, it can be expected that households will use the opportunities offered by renewable carriers in a wider scope.

\section{CONCLUSIONS}

The development of renewable energy sources (RES) is a factor affecting the entire economy and the household sector. It is difficult to increase the use of renewable energy in a large sector of households, where each consumer consumes approximately $2,150 \mathrm{kWh}$ annually. Despite the fact that households have a significant share in national energy consumption in Poland, renewable energy is still used in this sector to a small extent. In Poland, this is a factor slowing down the processes of modernization of the economy, encompassing rural areas. Changes in the area of RES reflect very slow structural transformations in relation to the EU. The potential for growth in the use of renewable energy depends not only on technological progress, but also on the dynamics of energy prices. In households, in particular, such renewable energy carriers as: water, wind or geothermal energy are utilized insufficiently. What is important in achieving a modern economy using RES, is not only the proper implementation of EU provisions to Polish law, but the implementation of effective mechanisms that enforce specific practices.

It is important to also introduce changes in the scope of statistical data collection connected with the necessity of regular and extended, regarding the subjective and objective scope, public statistics and the use of administrative data. The shortages of regularly collected data concern households in rural areas and agriculture-related areas. It also seems important to mitigate the social consequences of switching to clean energy while implementing appropriate support policies. In order for the potential offered by RES to be fully utilized, it is necessary to implement many instruments addressed to the household sector. These tools can be informative, educational, regulatory, financial and institutional. An appropriate direction here seems to be the promotion of the idea of prosumption, which will enable the modernization of this sector. This will become possible when the household is not only a consumer of energy, but also becomes its producer. Improvement in the use of renewable energy in the household sector will also be conducive to the construction of a modern and innovative economy and have a positive impact on improving the country's energy security.

\section{REFERENCES}

European Commission (2010). Energy 2020. A strategy for competitive, sustainable and secure Energy. Brussels.

FREE (2013). Modernizacja energetyczna polskiej wsi: w stronę energetyki prosumenckiej [Energy modernization of the Polish countryside: towards prosumer energy]. Warszawa.

Ginter, A., Kałuża, H., Dziubak, D. (2014). Wdrażanie projektów ekologicznych z wykorzystaniem wsparcia unijnego jako wyraz zrównoważonego rozwoju na przykładzie badanych gmin [Implementation of environmental projects with the use of EU support as an expression of sustainable development at the example of the surveyed municipalities]. Roczniki Naukowe SERiA, 16 (2), pp. 62-67.

Górecka-Zbrońska, A., Zbroński, D. (2017). Zmiana struktury zużycia energii w gospodarstwach domowych w kontekście stosowanych nośników energii [Change of energy consumption structure in households in context of used energy carrier]. Rynek Energii, 4 (131), pp. 22-31.

Gradziuk, P., Gradziuk, B. (2017). Próba oceny absorpcji środków z funduszy europejskich na rozwój wykorzystania odnawialnych źródeł energii w woj. lubelskim [An attempt to assess the absorption from European funds for the development of the use of renewable energy sources in the province Lublin]. Roczniki Naukowe Ekonomii Rolnictwa i Rozwoju Obszarów Wiejskich, 104 (3), pp. 95-105.

GUS (2016). Energia ze źródeł odnawialnych w roku 2015 [Energy from renewable sources in 2015]. Dział Wydawnictw Statystycznych GUS, Warszawa.

GUS (2017a). Energia ze źródeł odnawialnych w roku 2016 [Energy from renewable sources in 2016]. Dział Wydawnictw Statystycznych GUS, Warszawa. 
GUS (2017b). Budżety gospodarstw domowych w roku 2016 [Household budget survey in 2016]. Informacje i Opracowania Statystyczne. Dział Wydawnictw Statystycznych GUS, Warszawa.

GUS (2017c). Energia [Energy]. Dział Wydawnictw Statystycznych GUS, Warszawa.

GUS (2017d). Efektywność wykorzystania energii w latach 2005-2015 [Energy efficiency 2005-2015]. Informacje i Opracowania Statystyczne. Dział Wydawnictw Statystycznych GUS, Warszawa.

GUS (2017e). Zużycie energii w gospodarstwach domowych w roku 2016 [Energy Consumption in Households in 2016]. Informacje i Opracowania Statystyczne. Dział Wydawnictw Statystycznych GUS, Warszawa.

Księżopolski, K., Pronińska K. (2017). Studium barier administracyjnych i proceduralnych w rozwoju OZE na obszarach wiejskich [Study of administrative and procedural barriers in the development of renewable energy in rural areas]. Fundacja Europejski Fundusz Rozwoju Wsi Polskiej, Warszawa.

Malko, J., Wilczyński A., Wojciechowski, H. (2015). Bezpieczeństwo energetyczne, dostępność energii i zrównoważony rozwój a strategia unii energetycznej [Energy security, energy availability and sustainable development and the Energy Union strategy]. Rynek Energii, 2 (116), pp. 10-17.

Ministerstwo Energii (2015). Projekt Polityki energetycznej Polski do 2050 roku [The Polish Energy Policy Project until 2050]. Warszawa.

Ministerstwo Gospodarki (2011). Mix energetyczny 2050. Analiza scenariuszy dla Polski [Energy mix 2050. Analysis of scenarios for Poland]. Warszawa.

Ministerstwo Gospodarki (2014). Krajowy Plan Działań dotyczący efektywności energetycznej dla Polski [National Action Plan on energy efficiency for Poland]. Warszawa.
Ministerstwo Gospodarki (2014). Ocena realizacji Polityki energetycznej Polski do 2030 roku [Assessment of implementation of Polish Energy Policy until 2030]. Warszawa.

Ministerstwo Rolnictwa i Rozwoju Wsi (2017). Strategia Zrównoważonego Rozwoju Wsi, Rolnictwa i Rybactwa na lata 2017-2020 (2030) [Sustainable Rural Development, Agriculture and Fisheries Strategy for 2017-2020 (2030)]. Warszawa.

Mirowski, T., Orzechowska, M. (2015). Wykorzystanie paliw biomasowych w ogrzewnictwie indywidualnym na obszarach zagrożonych niską emisją [The use of biomass fuels in individual heating in areas threatened by low emissions]. Energy Energy Policy Journal, 18 (4), pp. $75-88$.

Mirowski, T., Sornek, K. (2015). Potencjał energetyki prosumenckiej w Polsce na przykładzie mikroinstalcji fotowoltaicznych $\mathrm{w}$ budownictwie indywidualnym [Potential of prosumer energy in Poland on the example of photovoltaic micro installations in private construction]. Energy Policy Journal, 18 (2), pp. 73-84.

PKN Orlen (2017). Gospodarka 4.0. Czas zmiany dla biznesu [Economy 4.0. Change time for business]. Warszawa.

Popczyk, J. (2014). Prosumenstwo - innowacja przełomowa [Prosumism - a breakthrough innovation]. Energetyka Cieplna i Zawodowa, 2, pp. 36-43.

Skoczkowski, T., Bielecki, S. (2016). Energy effectiveness - formal and political conditions for its development in Poland and the European Union. Energy Policy Journal, 19 (1), pp. 5-20.

Tokarčík, A., Rovňák M., Lechwar M., Wisz G. (2017). Zarządzanie energią w jednostkach samorządu terytorialnego. Wybrane modele - możliwości, ograniczenia, rekomendacje [Energy management in local government units. Selected models - possibilities, limitations, recommendations]. CeDeWu, Warszawa. 